\title{
UPTAKE AND TRANSLOCATION PATTERN OF HEAVY METALS IN LEAFY VEGETABLES HIGHLY CONSUMED IN TANZANIA
}

\author{
J.P. Muhondwa \\ School of Environmental Science and Technology, \\ Ardhi University, \\ P.O. Box 35176, Dar es Salaam, Tanzania
}

\author{
H. M. Mwombela \\ School of Environmental Science and Technology, \\ Ardhi University, \\ P.O. Box 35176, Dar es Salaam, Tanzania
}

Abstract - Health risks associated with consumption of leafy vegetables grown at the interface of nonpoint pollution sources is a growing public concern. This study investigated the uptake and translocation pattern of five heavy metals $(\mathrm{Cr}, \mathrm{Cd}, \mathrm{Cu}, \mathrm{Pb}$ and $\mathrm{Zn})$ in three leafy vegetables namely African spinach (Amaranth spp.), Chinese cabbage (Brassica chinensis) and Pumpkin plant (Moschata cucurbita) grown at Kichangani, Morogoro in Tanzania. Vegetables, soil, irrigation water and chicken manure samples were collected from vegetable growing plots and their heavy metals concentration determined by PerkinElmer Analyst 100 AAS. Except for $\mathrm{Cu}$ and $\mathrm{Cd}$ in soil, other heavy metals were found within the specified safe-limits. Chicken manure mainly contained $\mathrm{Cu}$ and $\mathrm{Zn}$. Although all heavy metals were uptaken in all vegetables, yet the accumulated portions were low to qualify the vegetables as hyperaccumulators. Generally, all vegetables showed low bioaccumulation factor $(\mathrm{BAF})<1$ implying their low affinity and poor phytoextraction potential to all heavy metals analyzed except for $\mathrm{Cr}$ which had $\mathrm{BAF}>1$ in Chinese cabbage. Having low bioconcentration factor (BCF) $<1$ in all vegetables signified their tolerance potential in restricting soil-roots and roots-shoots heavy metals transfer. $\mathrm{Cu}$ and $\mathrm{Zn}$ fetched high phytotranslocation factor (PTF) $>1$ in all leafy vegetables with African spinach and Pumpkin plant showing even higher PTF>1 for Cr. Since the onset of heavy metals toxicity and health risks depends on the intake frequency, the detection of heavy metals in edible parts of the vegetables therefore makes food safety associated with consumption of the leafy vegetables grown on contaminated areas questionable.

Keywords - Heavy metal, bioaccumulation, bioconcentration, phytotranslocation, leafy vegetables

\section{INTRODUCTION}

Consumption of leafy vegetables in every meal is highly recommended for both nutritional security (Singh et al. 2018) and medical grounds (Southon 2000; Oyebode et al. 2014). However, human health risks and toxicity associated with consumption of leafy vegetables grown at the interface of nonpoint pollution sources have raised public concern given the involving possibility of heavy metals uptake and accumulation in the vegetables' edible portions.

In many urban cities of developing countries including Tanzania, unreliability in supply and high tariff payable for piped water makes it not affordable for irrigation, hence low-quality irrigation water from polluted water sources become the solitary option (Mayilla et al. 2017). Land degradation and environmental pollution as a result of haphazardly dumping of comingled solid waste and poor management of industrial and domestic wastewater have deposited various contaminants in surface water sources and soils which are used for vegetable growing. Other named practices in environment and agriculture that elevate heavy metals in soil and consequence in vegetables include the use of industrial effluent for irrigation (Khan et al. 2019), the use of treated sewage sludge (McBride 1995; Zufiaurre et al. 1998), and recycling of wastewater on crop lands (Qian \& Mecham 2005). Absence of enough lands for gardening following urban development and cities expansion, have compelled some of the urban poor gardeners to scramble for the derelict sites including the highly polluted closed wastedumping sites and convert them into potential vegetables growing fields (Kihampa et al. 2011). On the other hand, land application of compost and digestate produced from commingled municipal solid waste, intensive use of inorganic fertilizers and chicken manure as soil conditioner equally exacerbates the problem given the concentration of heavy metals contained therein (Ramadan \& Al-Ashkar 2007).

Presently, the production and marketing of leafy vegetables in Tanzania is self-controlled with the quality and safety aspects of the produce solely resting upon the discreet of the producers (De Putter et al. 2007; Barham \& Chitemi 2009; Mithöfer \& Waibel 2011). Perishability nature of leafy vegetables and the absence of proper marketing channels make it difficult for the regulatory authorities undertake quality assurance and/or monitor their conformity to safe-limit standards. Leafy vegetables like other plant species may accumulate significant amount of heavy metals in their shoots, stems and roots depending on the physical and chemical nature of the soil under cultivation and absorption capacity of each heavy metal ion by the plant which is controlled by 


\section{International Journal of Engineering Applied Sciences and Technology, 2019 Vol. 4, Issue 6, ISSN No. 2455-2143, Pages 261-269 \\ Published Online October 2019 in IJEAST (http://www.ijeast.com)}

innumerable environmental factors (Bahemuka \& Mubofu 1999; Othman 2001; Chove et al. 2006; Yoon et al. 2006; Mwegoha \& Kihampa 2010). It is acknowledged that the fate and impact of heavy metal contamination depends on the fraction reversibly mobilized into soil solution and having compromised soil factors, become uptaken by plants and consequently incorporated into the food chain (Bahemuka \& Mubofu 1999; Eslami et al. 2007; Olayiwola 2013; Radulescu et al. 2013). In the quest to assess safety in edible portions of some leafy vegetables widely grown and highly consumed in Tanzania, the current study therefore determined the uptake capacity and translocation pattern of heavy metals in the vegetables and vegetable parts respectively. The study specific objectives were (1) to evaluate the accumulation of $\mathrm{Cd}, \mathrm{Cr}, \mathrm{Pb}$, $\mathrm{Zn}$ and $\mathrm{Cu}$ in three leafy vegetables namely African spinach (Amaranth spp.), Chinese cabbage (Brassica chinensis) and Pumpkin plant (Moschata cucurbita), and (2) to compare the heavy metal concentrations in vegetables aboveground against those in roots and the vegetable growing soil. To accomplish these objectives, soil, irrigation water and chicken manure from the vegetables growing field were equally collected and analyzed for their heavy metal content.

\section{MATERIALS AND METHODS}

\section{A. Characterization of a study area}

It is worth noting that the soil, weather and climatic condition of Tanzania generally support agriculture activities and favor a wide range of vegetables. In this study,
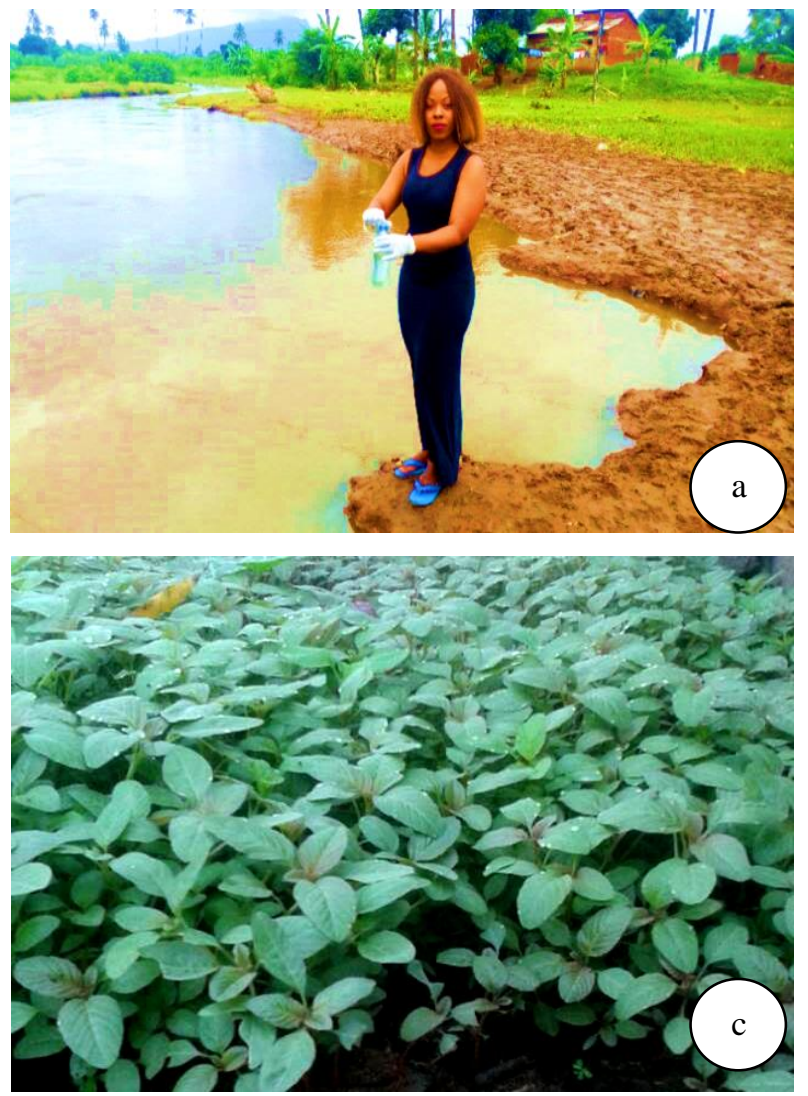

Kichangani which is one among the 29 administrative wards in Morogoro urban was selected to be a case study area. Applying the annual intercensal growth rate of $2.4 \%$ as reported in the 2012 Tanzania Population and Housing Census general report (Tanzania, 2013), the ward's current population stands at 22,500 of which majority are farmers including vegetable growers and/or sellers. The cultivation of the leafy vegetables is done at a site well known as Darajani which is adjacent to Morogoro River (Fig. 1a). Most of the leafy vegetables commonly grown at this area include Pumpkin leaves (Fig. 1b), African spinach (Fig. 1c) and Chinese cabbage (Fig. 1d). In order to enhance soil fertility and improve vegetable growth, the vegetable growers intensively apply fresh chicken manure $(\approx 50 \mathrm{~kg}$ per $12 \mathrm{sqm})$ collected from the coops of indoor kept exotic chicken, a common situation applicable to most vegetable growers in the country.

\section{B. Sample collection}

The three common leafy vegetables (African spinach, Chinese cabbage and Pumpkin plant) were selected for this study based on the criterion that the vegetables are not only cultivated in many other parts of the country but also form part of the daily cuisine to almost all Tanzanians. Irrigation water from Morogoro River, soil, and chicken manure used as soil enrichment were collected to determine heavy metal dispersion and therefore bioavailability for uptake in the vegetables. Sampling point locations are as indicated in Fig. 2.
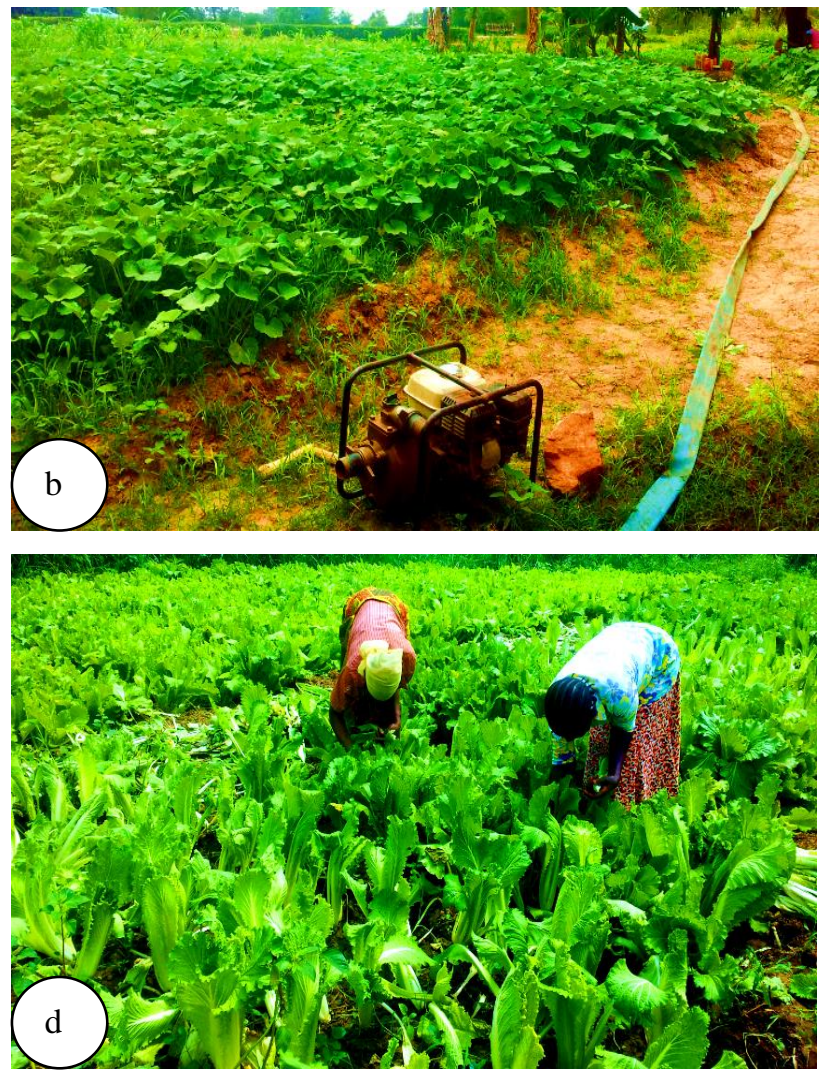

Fig. 1. (a) Sampling of water used for irrigating leafy vegetables, (b) Water pump irrigating pumpkin plants at the study area, (c) African spinach 


\section{International Journal of Engineering Applied Sciences and Technology, 2019 \\ Vol. 4, Issue 6, ISSN No. 2455-2143, Pages 261-269 \\ Published Online October 2019 in IJEAST (http://www.ijeast.com)}

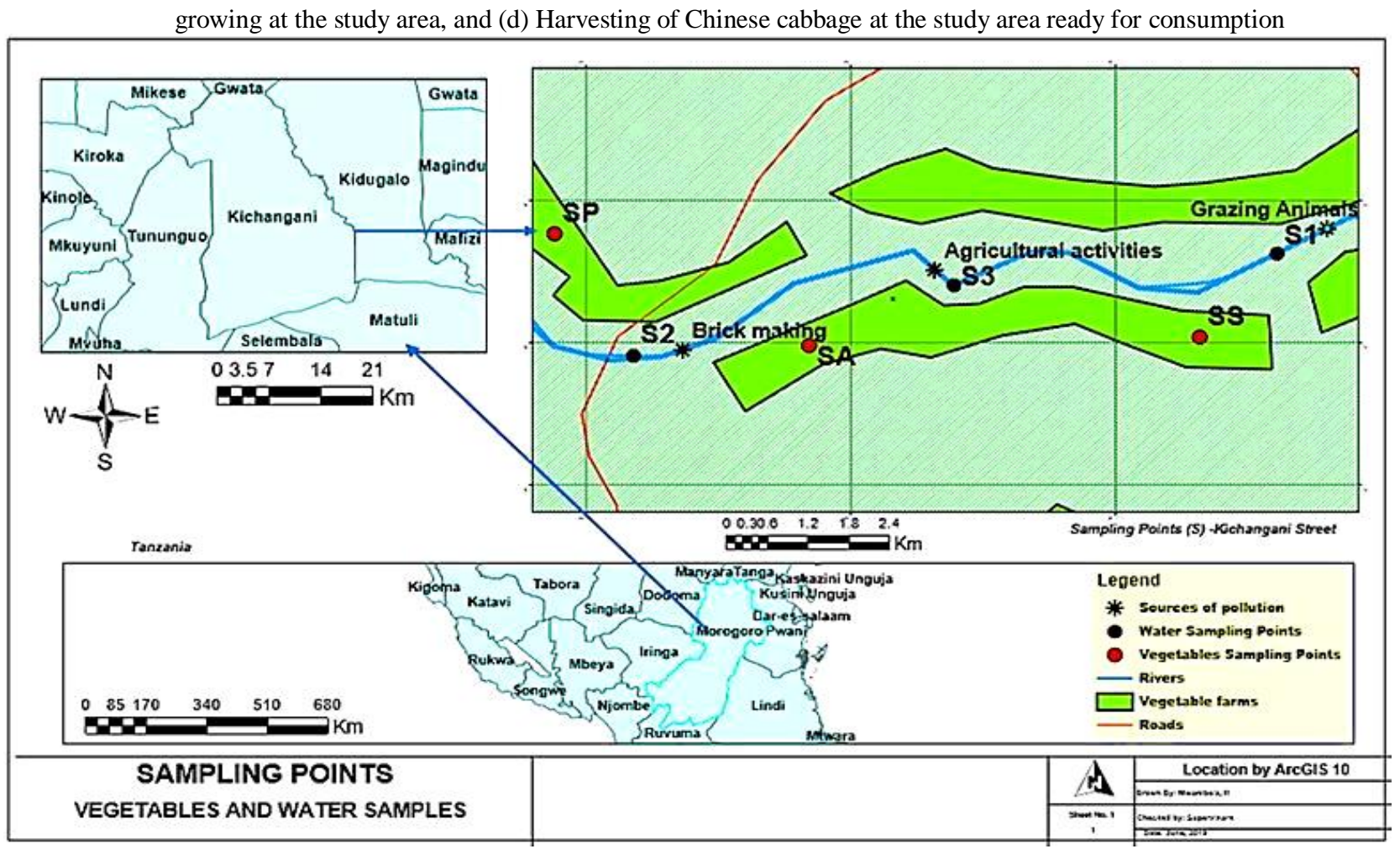

Fig. 2. Location of Kichangani ward, vegetable growing plots and sample collection points

From each vegetable growing plot several whole vegetable plants (roots and shoots) were randomly uprooted by hands and collected into separate clean plastic buckets. A composite sample of about 3 liters of irrigation water from Morogoro river was collected from 3 different locations coded: S $\mathrm{S}_{1}\left(6^{0} 47^{\prime} 55.40^{\prime \prime} \mathrm{S} / 37^{0} 40^{\prime} 27.19^{\prime \prime} \mathrm{E}\right), \mathrm{S}_{2}$ (6 $6^{0} 47^{\prime} 56.17^{\prime \prime} \mathrm{S}$ $137^{0} 40^{\prime} 27.04$ 'E) and $S_{3}\left(6^{0} 47^{\prime} 56.12^{\prime \prime S} / 37^{0} 40^{\prime} 26.25^{\prime \prime} \mathrm{E}\right)$. Sampling point $S_{1}$ was taken at a distance approximately 30 meters from the bridge, a point with livestock passage where animals-fecal wastes presumably get washed into the river. Sampling point $S_{2}$ was taken closer to a place where production of cement blocks takes place while sampling point $\mathrm{S}_{3}$ was from an area with intensive vegetables growing activities. About $0.5 \mathrm{~kg}$ of soil sample was collected from each vegetables growing plot using a polyethylene spoon at a depth of $0-20 \mathrm{~cm}$. This soil depth was selected after measuring the root length of several vegetable samples.

The soil samples collected were labeled in accordance to the leafy vegetable grown, that means: $S_{A}, S_{C}$ and $S_{P}$ denoting the soil from a plot growing African spinach, a plot growing Chinese cabbage and a plot growing pumpkin plants respectively. A sample of about $0.5 \mathrm{~kg}$ fresh chicken manure was equally scooped from several bags that were present at the case study area before being applied on a newly nursery prepared for new seeding or transplanting of new vegetables.

\section{Sample preparation and treatment for heavy metal analysis}

The uprooted vegetable samples were thoroughly cleaned using clean tap water to remove soil particles, dust and extraneous matter or any superficial contaminants from atmospheric deposition. The cleaned vegetables were further rinsed in deionized water that has been prepared using Bibby Merit Water Still W4000 distiller and then deionized using Elgastat Micromeg column to ensure a complete removal of all ions. Reagents of analytical grade were used as received throughout the study. All laboratory equipment and glassware for sample handling were used after being soaked in $0.5 \%$ (v/v) $\mathrm{HNO}_{3}$ overnight followed by thorough rinsing in deionized water. Using a clean stainless steel knife, the cleaned vegetables were chopped into three parts: the leaves, the stems and the roots. A blender (Multipro compact blender) having 1.5 liter capacity was used for size reduction of the chopped vegetable portions. The blended samples were ovendried at $60^{\circ} \mathrm{C}$ to constant weight and stocked in polyethylene bags at room temperature $\left(25^{\circ} \mathrm{C}\right)$ prior to digestion. On the other hand, soil and chicken manure samples were each sieved through a $2-\mathrm{mm}$ nylon sieve, oven-dried at $60^{\circ} \mathrm{C}$ to constant weight then stocked in polyethylene bags at room temperature prior to digestion process.

\section{Analytical methods}

Applying a method described in Smith-Weldon method (Nelson \& Sommers 1982), the selected physicochemical parameters ( $\mathrm{pH}$, salinity and electrical conductivity) of soil and irrigation water were determined using a $\mathrm{pH}$ meter 


\section{International Journal of Engineering Applied Sciences and Technology, 2019 Vol. 4, Issue 6, ISSN No. 2455-2143, Pages 261-269 \\ Published Online October 2019 in IJEAST (http://www.ijeast.com)}

(WTW inoLab with \pm 0.01 precision), salinity meter (WTW, TetraCon ${ }^{\circledR}$ 325) and EC meter (Hanna EC meter H198353 DiST-3) respectively. A jar test method was used for soil texture determination. Soil texture classes were determined from the collected soil and the corresponding percent of soil separates confirmed by a soil-texture-triangle. Total organic matter (TOM) content in soil was determined as percent of loss of ignition at $550^{\circ} \mathrm{C}$. Cation exchange capacity (CEC) was determined as the sum total of exchangeable cations (cmolc/kg) held in the soil. Analytical balance (Mettler Toledo AB204 with a precision of $\pm 0.1 \mathrm{mg}$ ) was used to weigh $3 \mathrm{~g}$ of each sample for digestion. As described in Alloway (2012), the prepared samples were each suspended in $250 \mathrm{~mL}$ pyrex digestion tubes and using aqua-regia digested as described in ISO 11466(1997). First, the pre-digestion step was done at room temperature for $16 \mathrm{~h}$ with $35 \% \mathrm{HCl}: 69 \% \mathrm{HNO}_{3}(3: 1)$ mixture. Then, the suspension was digested at $130^{\circ} \mathrm{C}$ for $2 \mathrm{~h}$ in a reflux condenser. The obtained suspension was filtered through an ash-free paper filter (Whatman 40), and its volume made up to $100 \mathrm{~mL}$ by addition of $0.5 \mathrm{~mol} / \mathrm{L} \mathrm{HNO}_{3}$. Blended vegetable leaves, stems and roots, and the prepared soil and the chicken manure samples were digested applying the same procedure. Soil wash-off was prepared by suspending $10 \mathrm{~g}$ of the prepared soil into $100 \mathrm{~mL}$ of deionized water $(\mathrm{S} / \mathrm{L}=1 / 10)$. The resulting solution was filtered through an ash-free paper filter (Whatman 40), and its volume was made up to $100 \mathrm{~mL}$ by addition of $0.5 \mathrm{~mol} / \mathrm{L} \mathrm{HNO}_{3}$.

Analysis of the five heavy metals $(\mathrm{Cr}, \mathrm{Cd}, \mathrm{Cu}, \mathrm{Pb}$ and $\mathrm{Zn}$ ) in the solution from leafy vegetable, soil, soil-wash-off, chicken manure and irrigation water samples was done using Perking Elmer Analyst 100 AAS coupled with Perking Elmer HGA 850 Graphite Furnace with a computer interface for operation and displaying the readings. Plant-uptaken and translocated heavy metals were calculated based on the three indices namely Bioaccumulation factor (BAF) denoting soilplant transfer factor, Bioconcentration factor (BCF) denoting soil-roots transfer factor, and Phytotranslocation factor (PTF) denoting root-shoots transfer factor (Mkumbo et al. 2012). These were calculated as ratio of metal in vegetables to that in soil, metal in roots to that in soil and metal in shoots to that in roots respectively.

\section{RESULTS AND DISCUSSION}

\section{E. Quality of irrigation water, soil and chicken manure}

The selected physical and chemical parameters of water at different sampling points from Morogoro River used for irrigation are shown in Table 1. As shown in the table, the $\mathrm{pH}$ of water ranges from nearly neutral to slightly alkaline yet within the recommended limits set by FAO (1989). The $\mathrm{pH}$ range between 6.5 and 8.4 is considered ideal for biological productivity. However, the alkaline $\mathrm{pH}$ range is preferred as it is suitable at minimizing heavy metals mobility hence reduces their concentration in water and consequently bioavailability. High $\mathrm{pH}$ of water makes heavy metals precipitate thus settles at the bottom of the sediments within the River. Slightly alkaline observed in $S_{1}$ and $S_{2}$ could be a result of limestone following dumping of cement remains from a block-laying activity taking place closer to the river. The electrical conductivities (EC) of water sample were observed to range from 644 to $759 \mu \mathrm{S} / \mathrm{cm}$. The EC of water sample from $S_{2}$ and $\mathrm{S}_{3}$ slightly exceeded the limit set by FAO (1989). Water sample from $\mathrm{S}_{3}$ showed higher EC because this point receives nutrients from agricultural runoffs that carry negatively charges ions such as nitrates. Higher EC is likely to affect soil permeability and damage roots resulting into nutrient imbalances and impair water and nutrients uptake. Other soluble salts concentrations in all samples were within the standards indicating water to be non-saline and therefore suitable for irrigation.

The concentration of $\mathrm{Pb}$ was observed to be relatively higher in the irrigation water though within the set-limits, in the second sampling point $\mathrm{S}_{2}$ the $\mathrm{Pb}$ concentration was up to $1.6 \pm 0.5 \mathrm{mg} / \mathrm{L}$. Heavy metals contamination sources and pathways are the determinant of the contamination trend. For instance, while the heavy metals concentration in the river were observed to be in the order of $\mathrm{Pb}>\mathrm{Zn}>\mathrm{Cr}>\mathrm{Cu}>\mathrm{Cd}$, Mishra et al.,(2019) in their study estimating heavy metal pollution in rivers at the interface of mining sites reported a trend of $\mathrm{Cu}>\mathrm{Zn}>\mathrm{Pb}$. All five heavy metals analyzed in water were within the allowable limits set by FAO for irrigation with $\mathrm{Cd}$ being below the limit of quantification. This is due to the fact that $\mathrm{Cd}$ is highly mobile in water and therefore easily leachable than other metal ions even at slightly alkaline condition.

The physical characteristics of the soil at $0-20 \mathrm{~cm}$ depth are shown in Table 2. Soil pH was in the range of 6.3 minimum to 8.1 maximum. Similarly to water matrix, heavy metal mobility decreases when the soil $\mathrm{pH}$ increases as it facilitates the precipitation of ions like hydroxides, carbonates and formation of organic complexes. Heavy metals are normally very mobile at soil $\mathrm{pH}<7$. From the results, since the obtained soil $\mathrm{pH}$ ranges slightly acidic, neutral to nearly alkaline therefore are likely to limit the mobilization and therefore accessibility of heavy metals by the plant roots.

Table-1 Physico-chemical characteristics of river water used for irrigation of the leafy vegetables, $n=3$

\begin{tabular}{|l|c|c|c|c|}
\hline \multirow{2}{*}{ Parameter } & \multicolumn{3}{|c|}{ Sampling location } & \multirow{2}{*}{ Limits } \\
\cline { 2 - 4 } & $\mathbf{S}_{\mathbf{1}}$ & $\mathbf{S}_{\mathbf{2}}$ & $\mathbf{S}_{\mathbf{3}}$ & $\begin{array}{c}\text { (1989) } \\
\text { pH }\end{array}$ \\
\cline { 2 - 4 } & $8.0 \pm 0.1$ & $8.2 \pm 0.1$ & $6.9 \pm 0.1$ & $6.5-8.4$ \\
\hline $\mathbf{E C}, \mu \mathrm{S} / \mathrm{cm}$ & $653.3 \pm 9.0$ & $713.0 \pm 1.1$ & $757.33 \pm 2.1$ & 700 \\
\hline Salinity, \%o & $0.07 \pm 0.04$ & $0.13 \pm 0.02$ & $0.2 \pm 0.01$ & $0.7-3.0$ \\
\hline $\mathbf{C r},(\mathrm{mg} / \mathrm{L})$ & $0.06 \pm 0.02$ & $0.04 \pm 0.02$ & $0.21 \pm 0.07$ & 0.1 \\
\hline $\mathbf{C d},(\mathrm{mg} / \mathrm{L})$ & $<\mathrm{LoQ}$ & $<\mathrm{LoQ}$ & $<\mathrm{LoQ}$ & 0.01 \\
\hline $\mathbf{P b},(\mathrm{mg} / \mathrm{L})$ & $1.2 \pm 0.7$ & $1.6 \pm 0.5$ & $1.1 \pm 0.4$ & 5.0 \\
\hline $\mathbf{Z n},(\mathrm{mg} / \mathrm{L})$ & $0.2 \pm 0.6$ & $0.13 \pm 0.18$ & $0.28 \pm 0.24$ & 2.0 \\
\hline $\mathbf{C u},(\mathrm{mg} / \mathrm{L})$ & $0.06 \pm 0.19$ & $0.03 \pm 0.21$ & $0.05 \pm 0.24$ & 0.2 \\
\hline
\end{tabular}




\section{International Journal of Engineering Applied Sciences and Technology, 2019 Vol. 4, Issue 6, ISSN No. 2455-2143, Pages 261-269 \\ Published Online October 2019 in IJEAST (http://www.ijeast.com)}

$S_{1}, S_{2}$ and $S_{3}$ denote the sampling points within the river. Results given as confidence interval for $95 \%$ confidence level, $<\mathrm{LoQ}=$ below limit of quantification

Relatively higher EC value $(821 \mu \mathrm{S} / \mathrm{cm})$ was observed in the soil growing African spinach i.e. $\mathrm{S}_{\mathrm{A}}$. Higher electrical conductivity could have been contributed by high clay content because clay soil has high capacity to strongly hold cations and nutrients. High EC in $\mathrm{S}_{\mathrm{A}}$ can also be due to high salinity that was in the range of $0.3 \%$ to $1.3 \%$. Soil textural classes were similar for $S_{A}, S_{c}$ and $S_{P}$ (Sand clay loam). Total organic matter (TOM) was observed to be higher compared to the values reported in other studies (Saglam 2013). This could be effected by the intensive use of chicken manure and decomposition of mulching materials applied on vegetable growing plots whose effects are also reflected on the observed cation exchange capacity (CEC) and the elevated EC and salinity values. Chicken manure was found to contain mainly $\mathrm{Cu}$ and $\mathrm{Zn}$ at $47.56 \pm 0.03 \mathrm{mg} / \mathrm{kg}$ and $51.03 \pm 0.26 \mathrm{mg} / \mathrm{kg}$ respectively, with traces of $\mathrm{Pb}=0.29 \mathrm{mg} / \mathrm{kg}, \mathrm{Cd}=0.31 \mathrm{mg} / \mathrm{kg}$ and $\mathrm{Cr}=0.17 \mathrm{mg} / \mathrm{kg}$ which reflect the additives and mineral supplements added into chicken feeds to facilitate growth and productivity (Okoye et al. 2011). Since the amounts of heavy metals in soil increase with decrease in the soil particle sizes, then clay soils are more likely to accumulate high amounts of heavy metals given their low infiltration rate and higher negatively charged colloidal particles which attract and hold the positively charged metal ions.

Table 2 - Selected characteristics of soil used for growing leafy vegetables

\begin{tabular}{|c|c|c|c|}
\hline \multirow[b]{2}{*}{ Parameters } & \multicolumn{3}{|c|}{ Sampling location } \\
\hline & $\mathbf{S}_{\mathrm{A}}$ & $\mathbf{S}_{\mathrm{c}}$ & $\mathbf{S}_{\mathbf{P}}$ \\
\hline pH & $6.5 \pm 0.2$ & $7.1 \pm 0.5$ & $7.7 \pm 0.4$ \\
\hline EC, $\mu \mathrm{S} / \mathrm{cm}$ & $821.0 \pm 0.4$ & $782.0 \pm 0.8$ & $730.0 \pm 0.5$ \\
\hline Salinity, \%o & $0.8 \pm 0.5$ & $0.7 \pm 0.2$ & $0.5 \pm 0.3$ \\
\hline CEC $\mathrm{cmol}_{\mathrm{C}} / \mathrm{kg}$ & 16.4 & 17.2 & 21.3 \\
\hline TOM, (\%) & 13.5 & 11.4 & 12.1 \\
\hline Sand: 0.05 - $2.0 \mathrm{~mm}(\%)$ & 66.7 & 56.8 & 52.7 \\
\hline Silt: $0.002-0.05 \mathrm{~mm}(\%)$ & 10.3 & 27.2 & 18.8 \\
\hline Clay $:<0.002 \mathrm{~mm}(\%)$ & 28.5 & 16.0 & 23.0 \\
\hline
\end{tabular}

Results given as confidence interval for $95 \%$ confidence, $\mathrm{TOM}=$ total organic matter; $\mathrm{S}_{\mathrm{A}}, \mathrm{S}_{\mathrm{S}}$ and $\mathrm{S}_{\mathrm{P}}$ refer to soil sample taken from African spinach, Chinese cabbage and Pumpkin leaves growing plots

Table 3 shows the results of pseudo-total heavy metal concentration in the soil sample from the vegetable growing plots. As expected, the soil on plot growing African spinach had slightly elevated heavy metals following immobilization as it consist high clay content compared to the other two plots. Closer to a vegetable growing field, there exists several heaps of illegal haphazardly dumped solid wastes; livestock passways with animal fecal matter, heavy road traffic and railway, small scale bricks and block laying facilities altogether being possible contamination sources to both soil and the river. As urged in Yoon et al., (2006), there were a strong correlation between $\mathrm{Pb}, \mathrm{Zn}$ and $\mathrm{Cu}$ observed which much corresponds to their similar contamination sources.

Metals buildup in clay soils would intensify the exposure of vegetable roots to higher amount increasing the chance of metals uptake should more metal ions become remobilized into the soil solution. All heavy metals in soil were above detectable range in the order of $\mathrm{Cu}>\mathrm{Zn}>\mathrm{Pb}>$ and $\mathrm{Cd}>\mathrm{Cr}$. $\mathrm{Cu}$ and $\mathrm{Cd}$ were above the set limits for allowable metal content in soil intended for agriculture as specified in the Junta de Andalucía (Spain).

Research on the distribution of heavy metals in the soil (Turekian \& Wedepohl 1961) reveal that $\mathrm{Cd}, \mathrm{Pb}$ and $\mathrm{Zn}$ much occupy the upper layer of the soil up to a distance of $30 \mathrm{~cm}$ down the soil profile. $\mathrm{Cu}$ is equally concentrated on the upper layer but only to a shorter distance about 7-10cm deep thereafter it assumes the soil generic reference value before its concentration increases again at $25-30 \mathrm{~cm}$. $\mathrm{Cr}$ is a peculiar metal in the trend as it is not easily found on the upper soil layer until $20-30 \mathrm{~cm}$ deep where the concentration could be deposited beyond a concentration of $20 \mathrm{mg} / \mathrm{kg}$. This is the reason behind the observed low concentration of $\mathrm{Cr}$ in the soil since the depth considered feasible for sample collection was based on how far the taproot of the leafy vegetable could deep-go, although this could not be always the case owing to the fact that the contaminants in the soil solution reaches plants root zone in a number of mechanisms including capillary rise deploying both cohesion and adhesion forces.

Table 3-Pseudo-total heavy metals content in soil samples $(\mathrm{mg} / \mathrm{kg})$, $\mathrm{n}=3$ for $95 \%$ confidence

\begin{tabular}{|c|c|c|c|c|}
\hline \multirow{2}{*}{$\begin{array}{c}\text { Heavy } \\
\text { metal }\end{array}$} & \multicolumn{3}{|c|}{ Extractable in Aqua-regia } & *Allowable \\
\cline { 2 - 4 } & $\mathbf{S}_{\mathbf{A}}$ & $\mathbf{S}_{\mathbf{c}}$ & $\mathbf{S}_{\mathbf{p}}$ & \\
\hline $\mathbf{C r}$ & $5.5 \pm 0.3$ & $4.2 \pm 0.8$ & $4.7 \pm 0.2$ & 100 \\
\hline $\mathbf{C d}$ & $6.1 \pm 0.1$ & $6.6 \pm 0.3$ & $6.2 \pm 0.2$ & 2 \\
\hline $\mathbf{P b}$ & $23.3 \pm 0.1$ & $15.1 \pm 0.5$ & $13.2 \pm 0.2$ & 100 \\
\hline $\mathbf{Z n}$ & $128.2 \pm 0.9$ & $108.1 \pm 0.3$ & $124.2 \pm 0.3$ & 200 \\
\hline $\mathbf{C u}$ & $146.4 \pm 0.3$ & $143.2 \pm 0.4$ & $140.6 \pm 2.4$ & 100 \\
\hline
\end{tabular}

*Intervention limits specified in Junta de Andalucía (Martín et al. 2006) for Agriculture soil; $S_{A}, S_{S}$ and $S_{P}$ refer to the soil samples taken from plots used for growing African spinach, Chinese cabbage and Pumpkin plant respectively

Table 4 shows the results of heavy metals in soil water extract also called wash-off. The determined concentration is a result of heavy metals leachability from the reversibly sorbed fraction due to the shift in equilibrium. These results simulate therefore the bioavailable metal ions in the soil available for uptake by the vegetable roots immediately after irrigation or rainfall. Generally, results showed that, the two essential heavy metals $\mathrm{Zn}$ and $\mathrm{Cu}$ are more remobilized in water than the non-essential heavy metals i.e. $\mathrm{Pb}, \mathrm{Cd}$ and $\mathrm{Cr}$. Although the concentration of non-essential heavy metal extractable in water was below $5 \mathrm{mg} / \mathrm{kg}$, this neither guarantees a lower uptake nor safety to vegetables 


\section{International Journal of Engineering Applied Sciences and Technology, 2019 \\ Vol. 4, Issue 6, ISSN No. 2455-2143, Pages 261-269 \\ Published Online October 2019 in IJEAST (http://www.ijeast.com)}

consumers. Given the harvesting time of the specific vegetable ranging between 37-45days for African spinach, 50-90days for Chinese cabbage and 50-180days for Pumpkin leaves, the heavy metal from the soil-wash-off could be slowly absorbed and steadily bioaccumulate in the plant tissues. On average, the concentrations of heavy metal in the soil-wash-off onto which the roots are exposed of were in the order of $\mathrm{Cu}>\mathrm{Zn}>\mathrm{Cd}>\mathrm{Pb}>\mathrm{Cr}$ in soil growing African spinach $\left(\mathrm{S}_{\mathrm{A}}\right)$, $\mathrm{Cu}>\mathrm{Zn}>\mathrm{Pb}>\mathrm{Cd}>\mathrm{Cr}$ in soil growing Chinese cabbage $\left(\mathrm{S}_{\mathrm{c}}\right)$ and $\mathrm{Cu}>\mathrm{Zn}>\mathrm{Pb}>\mathrm{Cr}>\mathrm{Cd}$ in soil growing Pumpkin plants $\left(\mathrm{S}_{\mathrm{P}}\right)$. However, the efficiency of plant to absorb metals from the soil depends on the ability of roots to uptake the respective metals that means no matter how concentrated heavy metal is in the soil, each type of vegetable accumulates the particular heavy metal at varying amount.

Table 4-Concentration of heavy metal in soil-wash-off ( $\mathrm{mg} / \mathrm{kg}), \mathrm{n}=3$ for $95 \%$ confidence limit

\begin{tabular}{|c|c|c|c|}
\hline \multirow{2}{*}{ Heavy metal } & \multicolumn{3}{|c|}{ Extractable in water } \\
\cline { 2 - 4 } & $\mathbf{S}_{\mathbf{A}}$ & $\mathbf{S}_{\mathbf{c}}$ & $\mathbf{S}_{\mathbf{P}}$ \\
\hline $\mathbf{C r}$ & $1.5 \pm 0.3$ & $1.2 \pm 0.8$ & $1.4 \pm 0.1$ \\
\hline $\mathbf{C d}$ & $2.3 \pm 0.3$ & $1.5 \pm 0.5$ & $1.3 \pm 0.2$ \\
\hline $\mathbf{P b}$ & $2.1 \pm 0.1$ & $2.3 \pm 0.3$ & $2.2 \pm 0.6$ \\
\hline $\mathbf{Z n}$ & $23.5 \pm 0.4$ & $18.1 \pm 0.6$ & $14.2 \pm 0.2$ \\
\hline $\mathbf{C u}$ & $50.1 \pm 0.2$ & $28.2 \pm 0.1$ & $36.4 \pm 0.4$ \\
\hline
\end{tabular}

$\mathrm{S}_{\mathrm{A}}, \mathrm{S}_{\mathrm{S}}$ and $\mathrm{S}_{\mathrm{P}}$ refer to soil sample taken from African spinach, Chinese cabbage and Pumpkin leaves growing plots

Fig. 3, 4 and 5 present the results for heavy metal concentration in roots, stems and leaves for African spinach, Chinese cabbage and pumpkin plants in that order. As expected, the concentrations of heavy metals in the vegetables grown even on the same plot were different. This confirms that, heavy metal uptake in vegetables is independent of the initial concentration observed in the soil.

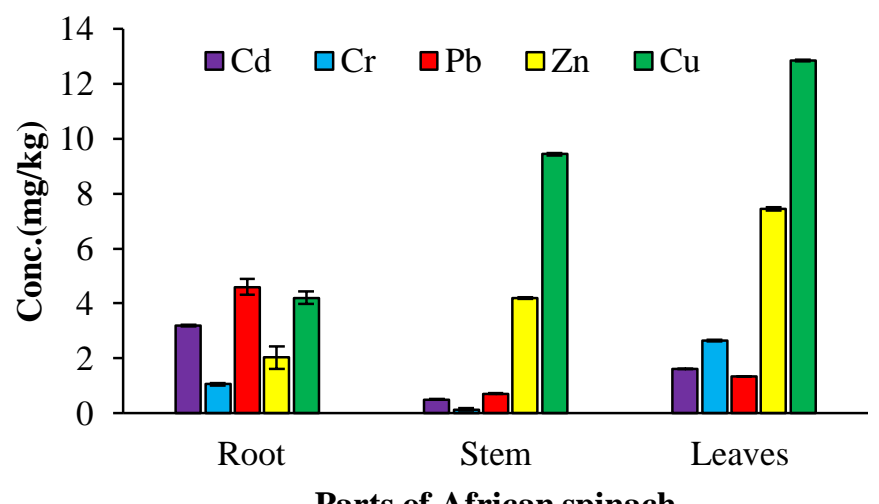

Fig. 3. Heavy metal concentrations in parts of African spinach

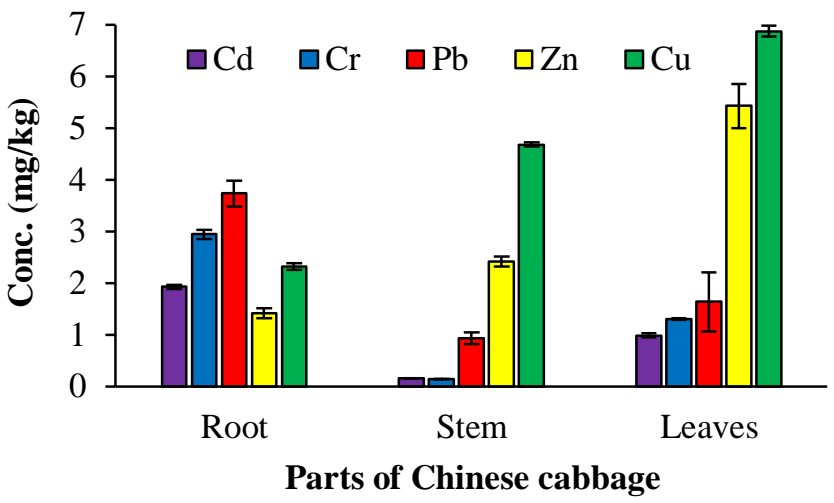

Fig. 4. Heavy metal concentrations in parts of Chinese cabbage

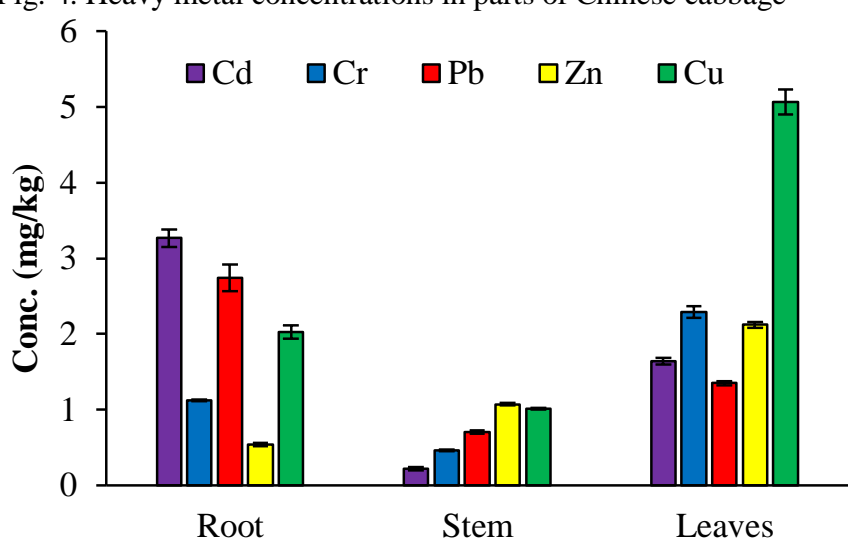

Parts of Pumpkin plants

Fig. 5. Heavy metal concentrations in parts of Pumpkin plants

Zurera-Cosano et al., (1989) in their work emphasized that, variations in the heavy metals uptaken and translocation pattern in plant parts depend on the physical and chemical nature of the soil, quality of irrigation water and absorption capacity of the plant. Heavy metals uptake from the soil to vegetables as in other plants occurs either passively with the mass flow of the soil-wash-off into the roots, or through active transport across the plasma membrane of root epidermal cells. Regardless of the initial heavy metals concentration in soil, plants can potentially accumulate certain heavy metal ions an order of magnitude greater than the surrounding medium. It was worth noting that no vegetable accumulated any heavy metal above $1000 \mathrm{mg} / \mathrm{kg}$ which is considered a cut-off point for a plant to qualify as potential hyperaccumulator (Yoon et al. 2006). African spinach was observed to accumulate relatively more of the heavy metals since it has longer taproot than the other two vegetable species. Using the longer roots, African spinach has the ability to therefore absorb and uptake metals that go deep-down beyond even the $20 \mathrm{~cm}$ sampling depth. Up to $12.9 \pm 0.04 \mathrm{mg} / \mathrm{kg}$ of $\mathrm{Cu}$ was found in the leaves of African spinach while in the steam there was up to $9.43 \pm 0.03 \mathrm{mg} / \mathrm{kg}$ of $\mathrm{Cu}$ and in the roots about $4.2 \pm 0.2 \mathrm{mg} / \mathrm{kg}$ of $\mathrm{Cu}$ (Fig. 3 ). Zn was the second highly translocated heavy metals $(7.4 \pm 0.1 \mathrm{mg} / \mathrm{kg})$ to the leaved of 


\section{International Journal of Engineering Applied Sciences and Technology, 2019 Vol. 4, Issue 6, ISSN No. 2455-2143, Pages 261-269 \\ Published Online October 2019 in IJEAST (http://www.ijeast.com)}

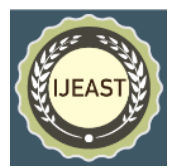

African spinach after $\mathrm{Cu}$. Although $\mathrm{Pb}$ and $\mathrm{Cd}$ are also highly absorbed in African spinach, $4.6 \pm 0.3 \mathrm{mg} / \mathrm{kg}$ and $3.20 \pm 0.03 \mathrm{mg} / \mathrm{kg}$ respectively, more of the absorbed portions are retained in the roots.

While $\mathrm{Pb}$ and $\mathrm{Cd}$ were $<2.0 \mathrm{mg} / \mathrm{kg}$, there was an elevated translocation of $\mathrm{Cr}$ up to $2.65 \pm 0.02 \mathrm{mg} / \mathrm{kg}$ detected in the leaves of African spinach. The low $\mathrm{pH}$ observed in soil growing African spinach could be an important influencing factor as well for more metal leachability and remobilization in the soil solution leading to an enhanced absorption and consequentially uptake. Similarly, Chinese cabbage was observed to translocate more $\mathrm{Cu}$ to the leaves up to $6.9 \pm 0.1 \mathrm{mg} / \mathrm{kg}$ and $\mathrm{Zn}$ up to $5.4 \pm 0.4 \mathrm{mg} / \mathrm{kg}$ (Fig. 4). The three non-essential heavy metals: $\mathrm{Pb}, \mathrm{Cr}$ and $\mathrm{Cd}$ though uptaken, they were highly stored in the roots part while some of the $\mathrm{Cu}$ and $\mathrm{Zn}$ were accumulated in the stem.

Pumpkin plant was observed to be comparatively inefficient in up-taking of the heavy metals from the soil solution. There was up to $5.1 \pm 0.2 \mathrm{mg} / \mathrm{kg}$ of $\mathrm{Cu}$ translocated to the leaves (Fig. 5). However, more $\mathrm{Cr}$ up to $2.60 \pm 0.07 \mathrm{mg} / \mathrm{kg}$ were found in the pumpkin leaves unlike in the Chinese cabbage leaves which had only $1.30 \pm 0.02 \mathrm{mg} / \mathrm{kg}$ and African spinach which had $2.3 \pm 0.1 \mathrm{mg} / \mathrm{kg}$ of $\mathrm{Cr}$. It is worth noting that $\mathrm{Cu}$ and $\mathrm{Zn}$ are essential micronutrients required in the human body and plants to support some physiological functions and build-up of structures hence are considered vital elements. However there exists a threshold concentration beyond which the metal becomes toxic. For plants, $\mathrm{Cu}$ and $\mathrm{Zn}$ take part in supporting growth and development, therefore highly needed in the leaves and stems. Despite these vegetables accumulating high concentration of $\mathrm{Cu}$ in the leaves, there was no chronic toxicity symptoms observed to the vegetables parts suggesting that plants could have adopted toxicity tolerance due to a long exposure by storing excess metals to cellular compartments like vacuole where the heavy metals could do the least and insignificant harm to the cellular processes.

\section{F. Heavy metals indices in vegetables aboveground and those in roots and soils}

Heavy metal accumulation indices for the vegetables are given in Table 5. It was observed that, heavy metal portion leached into soil solution and up-taken by vegetable roots was transferred to the edible portion of the vegetables at different rate and amount. The bioaccumulation factor (BAF) gives estimation of the expected human risks associated with heavy metal concentration in the vegetable plant as a whole. With exception to Chinese cabbage which showed $\mathrm{BAF}>1$ for $\mathrm{Cr}$ indicating its potential for uptake of this non-essential heavy metal, the other leafy vegetables bioaccumulated certain amount of heavy metals differently but at low concentration compared to the one in the respective soil hence demonstrating BAF <1. With lower BAF but higher PTF, all three leafy vegetables could be considered potential for phytoextraction of $\mathrm{Cu}$ and $\mathrm{Zn}$ as the phytoextraction process requires the uptaken heavy metals be translocated to the plants aerial parts (stem and leaves) for ease harvesting (Yoon et al. 2006). Although the amount of $\mathrm{Cu}$ and $\mathrm{Zn}$ accumulated in the leaves is insignificant and economically not-worthwhile to deploy for extraction process, these leafy vegetables could better serve as whole functional food to be recommended highly in case of $\mathrm{Cu}$ and $\mathrm{Zn}$ deficiency provided the risks from the nonessential heavy metals have been confirmed to be negligible. Considering the determined heavy metals concentration in the soil, relatively higher $\mathrm{Cd}$ is absorbed in African spinach $\mathrm{BAF}=0.87$ followed by pumpkin plants $\mathrm{BAF}=0.83$ and the Chinese cabbage was the least by demonstrating the $\mathrm{BAF}=0.47$, of which not much is translocated to the leaves. The uptake of $\mathrm{Cu}$ and $\mathrm{Zn}$ was similar in all vegetables following the order of African spinach>Chinese cabbage $>$ Pumpkin plant while that for $\mathrm{Pb}$ followed the order of Chinese cabbage $>$ Pumpkin plant $>$ African spinach.

$\mathrm{BCF}$ and PTF ideally compare the translocation potential of plants moving heavy metals uptaken to the plants aerial parts. Vegetables with $\mathrm{BCF}>1$ and $\mathrm{PTF}<1$ are generally categorized as potential phytostabilizers (Cheraghi et al. 2011; Mkumbo et al. 2012). Low BCF values <1 and PTF values <1 observed in various heavy metals indicates that the vegetables are tolerant to those heavy metals, therefore their transfer are restricted from soil to roots and roots to shoots (stem and leaves) (Yoon et al. 2006) categorizing the vegetables as excluders which inferred that the vegetables have low affinity to the heavy metals in the respective soils. High PTF values $=2.65$ and 2.45 observed for $\mathrm{Cr}$ in African spinach and Pumpkin plant suggest that more of the heavy metal is translocated to the leaves with no stabilization in the roots due to the demonstrated low BCF of 0.16 and 0.24 respectively. This result therefore suggest that, cultivation of either African spinach or pumpkin plants on site contaminated with $\mathrm{Cr}$ should be avoided since a long continuous consumption of these vegetables may result into build-up and accumulation of $\mathrm{Cr}$ in the cells of human body and pose significant health effects and toxicity.

High PTF values for $\mathrm{Cu}$ and $\mathrm{Zn}$ were observed in all leafy vegetables. This correlation suggests that, the plants which are effective at translocating $\mathrm{Cu}$ are equally suitable for translocating Zn. Being essential plant's micronutrients, both $\mathrm{Zn}$ and $\mathrm{Cu}$ demonstrated $0 \leq \mathrm{BCF} \leq 0.70$. This showed very small retention of the two metals in the roots of the three leafy vegetables and almost the whole up-taken portions were translocated in the vegetables aboveground considering the high $\mathrm{PTF}=5.29$ for $\mathrm{Cu}$ and $\mathrm{PTF}=5.74$ for $\mathrm{Zn}$ in African spinach, $\mathrm{PTF}=5.53$ for $\mathrm{Cu}$ and $\mathrm{PTF}=4.99$ for $\mathrm{Zn}$ in Chinese cabbage and $\mathrm{PTF}=5.96$ for $\mathrm{Cu}$ and $\mathrm{PTF}=3.00$ for $\mathrm{Zn}$ in Pumpkin plant. 


\section{International Journal of Engineering Applied Sciences and Technology, 2019 \\ Vol. 4, Issue 6, ISSN No. 2455-2143, Pages 261-269 \\ Published Online October 2019 in IJEAST (http://www.ijeast.com)}

Table 5- Heavy metal indices in the leafy vegetables

\begin{tabular}{|c|c|c|c|c|c|c|c|c|c|}
\hline \multirow{2}{*}{ Heavy metal } & \multicolumn{3}{|c|}{ African spinach } & \multicolumn{3}{c|}{ Chinese cabbage } & \multicolumn{3}{c|}{ Pumpkin plant } \\
\cline { 2 - 10 } & BAF & BCF & PTF & BAF & BCF & PTF & BAF & BCF & PTF \\
\hline $\mathrm{Cd}$ & 0.87 & 0.52 & 0.66 & 0.47 & 0.29 & 0.59 & 0.83 & 0.53 & 0.57 \\
\hline $\mathrm{Cr}$ & 0.59 & 0.16 & $\mathbf{2 . 6 5}$ & $\mathbf{1 . 0 5}$ & 0.70 & 0.49 & 0.82 & 0.24 & $\mathbf{2 . 4 5}$ \\
\hline $\mathrm{Pb}$ & 0.29 & 0.20 & 0.45 & 0.42 & 0.25 & 0.69 & 0.36 & 0.21 & 0.75 \\
\hline $\mathrm{Cu}$ & 0.18 & 0.03 & $\mathbf{5 . 2 9}$ & 0.09 & 0.01 & $\mathbf{5 . 5 3}$ & 0.03 & 0.00 & $\mathbf{5 . 9 6}$ \\
\hline $\mathrm{Zn}$ & 0.11 & 0.02 & $\mathbf{5 . 7 4}$ & 0.10 & 0.02 & $\mathbf{4 . 9 9}$ & 0.06 & 0.01 & $\mathbf{3 . 0 0}$ \\
\hline
\end{tabular}

$\mathrm{BAF}=$ metal concentration ratio of the whole plant to soil $\mathrm{BCF}=$ metal concentration ratio of plant roots to soil and PTF $=$ metal concentration ratio of plant shoots (stem and leaves) to roots. Indices values $>1$ are bolded.

\section{CONCLUSIONS AND RECOMMENDATIONS}

\section{G. Conclusion}

Vegetables like other plants uptake heavy metals at different rate and amount. Although the detection of heavy metals in the leafy vegetables make food safety aspect associated with their consumption questionable, a confirmation of where the metals are translocated and accumulated within vegetable's parts is vital in making informed decision on their consumption thus protect consumer health. Even though, $\mathrm{Zn}$ and $\mathrm{Cu}$ are essential element in the human diet, high accumulation in the vegetables edible portions call for routine monitoring to avoid toxicity to plants and health impact to consumers. Since heavy metals toxicity and health risks depends on the intake frequency, the detection of heavy metals in edible parts of the three leafy vegetables makes food safety associated with the consumption of the vegetables grown at heavy metals contaminated area questionable.

\section{H. Recommendations}

(i) There should be analysis of soil, water and manure for contamination verification on a field presumed to have been contaminated prior to commencing agriculture activities including the vegetables growing.

(ii) Intensive application of heavy metals contaminated manure and fertilizer on the vegetable growing fields should be replaced with other good agriculture practices so as to avoid heavy metal accumulation on the soil above the generic reference value that would enhance their uptake.

(iii) To minimize consumer health risks, heavy metal bioaccumulation (BAF), bioconcentration (BCF) and phytotranslocation (PTF) factors are to be used as indicators of the plant accumulation behavior and only the vegetables with low metal uptake potential are to be grown if the area is confirmed to have been contaminated with a specific heavy metal.

(iv) Soil stabilization should be encouraged to all agriculture fields presumed to be contaminated with heavy metals.
The use of soil stabilizers form insoluble bond with the heavy metal, raise the $\mathrm{pH}$ of the polluted soil and thus increase heavy metal sorption capacity of the soil and decrease metal leachability and mobility.

\section{ACKNOWLEDGEMENTS}

The authors gratefully acknowledge Ardhi University through the School of Environmental Science and Technology for availing resources necessary for conducting lab-based experiments. A vote of thanks is extended to Mr. R. Mbulume for technical assistance.

\section{VI: REFERENCES}

Alloway, B.J. (2012). Heavy metals in soils: trace metals and metalloids in soils and their bioavailability. Springer Science $\&$ Business Media.

Bahemuka, T., and Mubofu, E. (1999). Heavy metals in edible green vegetables grown along the sites of the Sinza and Msimbazi rivers in Dar es Salaam, Tanzania. Food Chemistry, 66,(pp. 63-66).

Barham, J., and Chitemi, C. (2009). Collective action initiatives to improve marketing performance: Lessons from farmer groups in Tanzania. Food policy, 34,(pp. 53-59).

Cheraghi, M., Lorestani, B., Khorasani, N., Yousefi, N. , and Karami, M. (2011). Findings on the phytoextraction and phytostabilization of soils contaminated with heavy metals. Biological trace element research, 144, (pp.1133-1141).

Chove, B., Ballegu, W. , and Chove, L. (2006). Copper and Lead levels in two popular leafy vegetables grown around Morogoro Municipality, Tanzania. Tanzania Journal of Health Research, 8, (pp.37-40).

De Putter, H., Van Koesveld, M. , and De Visser, C. (2007). Overview of the vegetable sector in Tanzania.

Eslami, A., Khaniki, G.J., Nurani, M., Mehrasbi, M., Peyda, M. , and Azimi, R. (2007). Heavy metals in edible green vegetables grown along the sites of the Zanjanrood river in Zanjan, Iran. Journal of Biological Sciences, 7, (pp.943-948). ISO. (1997). 11466, 1997. Extraction of trace elements soluble in aqua regia.(ISO 11466: 1995). 


\section{International Journal of Engineering Applied Sciences and Technology, 2019 \\ Vol. 4, Issue 6, ISSN No. 2455-2143, Pages 261-269 \\ Published Online October 2019 in IJEAST (http://www.ijeast.com)}

Khan, Z.I., Ahmad, K., Rehman, S., Ashfaq, A., Mehmood, N., Ugulu, I. et al. (2019). Effect of Sewage Water on Accumulation of Metals in Soil and Wheat in Punjab, Pakistan. Pakistan Journal of Analytical \& Environmental Chemistry, 20, (pp. 60-66).

Kihampa, C., Mwegoha, W.J. , and Shemdoe, R.S. (2011). Heavy metals concentrations in vegetables grown in the vicinity of the closed dumpsite. Int. J. Environ. Sci, 2, (pp.889895).

Martín, J.A.R., Arias, M.L. , and Corbí, J.M.G. (2006). Heavy metals contents in agricultural topsoils in the Ebro basin (Spain). Application of the multivariate geoestatistical methods to study spatial variations. Environmental pollution, 144, (pp.1001-1012).

Mayilla, W., Keraita, B., Ngowi, H., Konradsen, F. , and Magayane, F. (2017). Perceptions of using low-quality irrigation water in vegetable production in Morogoro, Tanzania. Environment, development and sustainability, 19, (pp.165-183).

McBride, M.B. (1995). Toxic metal accumulation from agricultural use of sludge: are USEPA regulations protective? Journal of Environmental Quality, 24, 5-18.

Mishra, S., Singh, R. , and Kumar, B. (2019). The Estimation of Heavy Metals in Subarnarekha River at Mau Bhandar and Galudih Barrage, Jharkhand. 4, (pp. 84-86).

Mithöfer, D. , and Waibel, H. (2011). Vegetable production and marketing in Africa: socio-economic research. CABI.

Mkumbo, S., Mwegoha, W. , and Renman, G. (2012). Assessment of the phytoremediation potential for $\mathrm{Pb}, \mathrm{Zn}$ and $\mathrm{Cu}$ of indigenous plants growing in a gold mining area in Tanzania. International Journal of Ecology and Environmental Sciences, 2, (pp. 2425-2434).

Mwegoha, W. , and Kihampa, C. (2010). Heavy metal contamination in agricultural soils and water in Dar es Salaam city, Tanzania. African Journal of Environmental Science and Technology, 4, (pp.763-769).

Nelson, D. , and Sommers, L.E. (1982). Total carbon, organic carbon, and organic matter 1. Methods of soil analysis. Part 2. Chemical and microbiological properties, (pp. 539-579).

Okoye, C., Ibeto, C. , and Ihedioha, J. (2011). Assessment of heavy metals in chicken feeds sold in south eastern, Nigeria. Olayiwola, O. (2013). Accumulation and contamination of heavy metals in soil and vegetation from industrial area of Ikirun, Osun State, Nigeria. Glob J Pure Appl Chem Res [Internet], 1, (pp. 25-34).

Othman, O.C. (2001). Heavy metals in green vegetables and soils from vegetable gardens in Dar es Salaam, Tanzania. Tanzania Journal of Science, 27, (pp. 37-48).

Oyebode, O., Gordon-Dseagu, V., Walker, A. , and Mindell, J.S. (2014). Fruit and vegetable consumption and all-cause, cancer and CVD mortality: analysis of Health Survey for England data. J Epidemiol Community Health, 68, (pp.856862).

Qian, Y.L. , and Mecham, B. (2005). Long-term effects of recycled wastewater irrigation on soil chemical properties on golf course fairways. Agronomy Journal, 97, (pp.717-721).
Radulescu, C., Stihi, C., Popescu, I., Dulama, I., Chelarescu, E. , and Chilian, A. (2013). Heavy metal accumulation and translocation in different parts of Brassica oleracea L. Romanian Journal of Physics, 58, (pp. 1337-1354).

Ramadan, M.A. , and Al-Ashkar, E.A. (2007). The effect of different fertilizers on the heavy metals in soil and tomato plant. Australian Journal of Basic and Applied Sciences, 1, (pp.300-306).

Saglam, C. (2013). Heavy metal accumulation in the edible parts of some cultivated plants and media samples from a volcanic region in Southern Turkey. Ekoloji, 22, (pp. 1-8).

Singh, A., Dubey, P.K., Chaurasiya, R., Mathur, N., Kumar, G., Bharati, S. et al. (2018). Indian spinach: an underutilized perennial leafy vegetable for nutritional security in developing world. Energy, Ecology and Environment, 3, (pp. 195-205).

Southon, S. (2000). Increased fruit and vegetable consumption within the EU: potential health benefits. Food Research International, 33, (pp. 211-217).

Tanzania, U.R.T. (2013). 2012 Population and housing Census: Population distribution by administrative areas. National Bureau of Statistics and Office of Chief Government Statistician, Tanzania

Turekian, K.K. , and Wedepohl, K.H. (1961). Distribution of the elements in some major units of the earth's crust. Geological Society of America Bulletin, 72, (pp. 175-192).

Yoon, J., Cao, X., Zhou, Q. , and Ma, L.Q. (2006). Accumulation of $\mathrm{Pb}, \mathrm{Cu}$, and $\mathrm{Zn}$ in native plants growing on a contaminated Florida site. Science of the total environment, 368, (pp. 456-464).

Zufiaurre, R., Olivar, A., Chamorro, P. , and Callizo, A. (1998). Speciation of metals in sewage sludge for agricultural uses. Analyst, 123, (pp. 255-259).

Zurera-Cosano, G., Moreno-Rojas, R., Salmeron-Egea, J. , and Lora, R.P. (1989). Heavy metal uptake from greenhouse border soils for edible vegetables. Journal of the Science of Food and Agriculture, 49, (pp. 307-314). 